\title{
Diskresi dalam Implementasi Kebijakan Publik (Studi pada Implementasi Kebijakan BPJS-Kesehatan di Puskesmas Kepanjen)
}

\author{
Gatu Adie Pradana ${ }^{a}$ * \\ ${ }^{a}$ Universitas Brawijaya, Malang, Jawa Timur, Indonesia
}

\section{INFORMASI ARTIKEL}

\section{Article history:}

Dikirim tanggal: 18 Juli 2016

Revisi pertama tanggal: 17 Oktober 2016

Diterima tanggal: 01 November 2016

Tersedia online tanggal: 16 November 2016

Keywords: discretion, public policy, BPJS-Kesehatan

\begin{abstract}
BPJS-Kesehatan Policy as a top-down policy, Puskesmas position as the spearhead of health services, especially in Puskesmas Kepanjen Malang District. Issues that exist in this research is how the pattern of discretion occurs and how its impact on BPJS-Kesehatan policy implementation in the Puskesmas Kepanjen. Discretion occur at managerial levels, the changing patterns of communication and coordination by the Office of BPJS-Kesehatan, Public Health Service of Malang Regency and Puskesmas Kepanjen. There are several steps that can be taken to overcome such discretion. First the capitation system changes; strengthening and centralizing the BPJS-Kesehatan database; and the regulations that health centers can manage a budget independently.
\end{abstract}

\section{INTISARI}

Kebijakan BPJS-Kesehatan sebagai kebijakan top-down, memposisikan puskesmas sebagai ujung tombak pelayanan kesehatan, khususnya di Puskesmas Kepanjen Kabupaten Malang. Permasalahan yang diangkat dalam penelitian ini adalah bagaimana pola diskresi yang terjadi dan pengaruhnya terhadap implementasi kebijakan BPJS-Kesehatan di Puskesmas Kepanjen. Diskresi terjadi pada tingkatan manajerial, yaitu perubahan pola komunikasi dan koordinasi oleh Kantor BPJS-Kesehatan, Dinas Kesehatan Kabupaten Malang, dan Puskesmas Kepanjen. Terdapat beberapa langkah yang dapat ditempuh untuk mengatasi diskresi tersebut. Pertama dengan perubahan sistem kapitasi; penguatan dan pemusatan database BPJS-Kesehatan; dan adanya peraturan agar puskesmas dapat mengelola anggaran secara mandiri.

\section{Pendahuluan}

Salah satu kebijakan kesehatan dari pemerintah adalah Jaminan Kesehatan Nasional. Kebijakan ini bertujuan agar seluruh masyarakat dapat menerima pelayanan kesehatan yang merata dan adil dengan menggunakan sistem premi seperti pada asuransi kesehatan pada umumnya. Salah satu bentuk implementasi kebijakan ini adalah melalui Badan
Penyelenggara Jaminan Sosial (BPJS) yang selanjutnya disebut BPJS-Kesehatan. BPJS-Kesehatan menjamin setiap masyarakat memperoleh pelayanan kesehatan dengan sistem premi. Sesuai dengan manual pelaksanaan BPJS-Kesehatan, puskesmas dan klinik yang tergolong kedalam fasilitas kesehatan tingkat satu adalah fasilitas kesehatan pertama yang harus masyarakat gunakan untuk menerima pelayanan kesehatan. Manual pelaksanaan BPJS-Kesehatan 
menjabarkan bahwa fasilitas kesehatan tingkat satu yang ada didaerahnya harus dipilih salah satu oleh masyarakat (antara puskesmas atau klinik) yang kemudian akan tercantum di dalam kartu BPJS yang diterima.

Kebijakan BPJS tersebut menunjukkan bahwa puskesmas menjadi fasilitas kesehatan tingkat pertama yang harus dijangkau oleh masyarakat. Hal tersebut sesuai dengan pengertian Puskesmas menurut Widaningrum (2007) "The Puskesmas, an Indonesian acronym for (community) health center is at the forefront of government's effort in ensuring universal access to health service". Berdasarkan pernyataan tersebut maka puskesmas adalah ujung tombak pemerintah dalam memberikan pelayanan kesehatan, oleh karena itu kualitas Puskesmas harus terus ditingkatkan tidak hanya jumlah dokter, jumlah tenaga paramedis, dan kualitas obat, tetapi juga peningkatan kualitas secara menyeluruh.

Permasalahan yang terjadi dilapangan, beberapa Puskesmas menolak masyarakat yang ingin berobat dengan alasan faskes pilihannya adalah faskes lain. Namun pada Puskesmas yang lain pasien dapat dilayani. Hal ini menunjukkan pada tingkat implementasi paling depan pada kebijakan BPJS-Kesehatan dapat di implementasikan berbeda, tergantung dari bagaimana pemberi layanan mengambil keputusan.

Diskresi tersebut dapat menimbulkan masalah, yang pertama dapat mempengaruhi pelaksanaan pelayanan kesehatan dikarenakan berdasarkan peraturan pelaksanaan BPJS-Kesehatan, yang dapat dilayani difasilitas kesehatan tingkat pertama hanyalah masyarakat yang mempunyai kartu BPJS-Kesehatan dan yang telah mendaftar sesuai dengan faskes tingkat satu yang dipilih. Hal ini akan menimbulkan beban pelayanan bagi puskesmas tersebut, penambahan beban pelayanan juga berarti mengganggu hak masyarakat yang berhak atas pelayanan di faskes tersebut. Kedua, secara administratif pencatatan pasien yang berobat tidak sesuai dengan faskesnya dapat menimbulkan kerumitan dalam proses klaim dana BPJS-Kesehatan karena tidak sesuai dengan peraturan yang berlaku.

Ketiga, permasalahan yang muncul adalah permasalahan manajerial. Tentunya dengan diskresi tersebut terdapat peraturan-peraturan manajerial baik dari puskesmas maupun dari kebijakan BPJS-Kesehatan yang dilanggar. Pelaku diskresi memang pada umumnya dilakukan oleh pemberi layanan yang langsung berhadapan dengan masyarakat, jika hal itu terjadi maka ada pelampauan otoritas yang dilakukan. Persetujuan pasien yang tidak terdaftar dalam faskes merupakan otoritas dari manajer/ pengawas yang berposisi diatas pemberi layanan. Oleh karena itu, jika dilihat dari sisi manajerial, diskresi tidak boleh terjadi

Riset yang dilakukan oleh Julia Brockmann (2015) yang berjudul Unbureaucratic Behaviour among Street
Level Bureaucracts: The Case of the German State Police; berusaha untuk mengungkap faktor-faktor yang berpengaruh terhadap tindakan "unbureaucratic behaviour" (tindakan yang dilakukan oleh birokrat level bawah yang tidak sesuai dengan alur birokrasi dan peraturan yang berlaku dalam memberikan pelayanan publik maupun dalam implementasi sebuah kebijakan) yang terjadi pada lembaga Kepolisian Negara Jerman, unbureaucratic behaviour ini juga dapat berarti sebagai tindakan diskresi yang dilakukan oleh birokrat level bawah. Brockmann (2015) menjelaskan lebih lanjut faktor-faktor tersebut adalah inisiatif, kesiapan melaksanakan strategi, dan akses terhadap sumber daya. Inisiatif digambarkan sebagai upaya untuk keluar dari aturan birokratis yang berlaku oleh birokrat level bawah, birokrat level bawah melakukan improvisasi terhadap peran mereka dan bagaimana mereka menjalankan tugas mereka. Inisiatif ini tidak selalu dimaknai sebagai hal yang negatif, inisiasi birokrat level bawah dapat berupa upaya melakukan tugas dengan lebih efektif dan efisien sesuai dengan karakteristik pekerjaan yang mereka lakukan

Terkait dengan peran birokrat level bawah tersebut, Lipsky (1980) menjelaskan bahwa:

Public service workers who interact directly with citizens in the course of their jobs, and who have substantial discretion in the execution of their work are called street-level bureaucrats..... Typical street-level bureaucrats are teachers, police officers and other law enforcement personnel, social workers, judges, public lawyers and other court officers, health workers, and many other public employees who grant access to government programs and provide services within them.

Lipsky mendefinisikan birokrat level bawah sebagai setiap orang yang bekerja dalam pelayanan publik, di mana mereka berinteraksi langsung dengan masyarakat. Berdasarkan penjabaran Lipsky mengenai siapa saja yang termasuk ke dalam birokrat level bawah, dapat diketahui guru, polisi, pekerja sosial, hakim, pengacara publik, tenaga kesehatan merupakan birokrat level bawah. Birokrat level bawah perannya sangat penting dalam implementasi kebijakan, karena mereka yang berinteraksi langsung dan berhubungan langsung dengan stakeholder.

Berdasarkan hal tersebut maka dalam implementasi sebuah kebijakan peran birokrat level bawah sangat berpengaruh. Implementasi kebijakan dapat dilaksanakan sesuai dengan strategi dan model kebijakan, tetapi di sisi lain birokrat level bawah dapat pula mengimplementasikan kebijakan tersebut tidak sesuai dengan strategi yang ada. Tergantung dari persepsi dan kepentingan birokrat level bawah terhadap kebijakan tersebut. Oleh karena itu peneliti ingin mengetahui bagaimana bentuk diskresi yang terjadi dalam Implementasi Kebijakan BPJS-Kesehatan di 
Puskesmas Kepanjen dan bagaimana pengaruh diskresi tersebut terhadap Implementasi Kebijakan BPJSKesehatan di Puskesmas Kepanjen.

\section{Teori}

\subsection{Implementasi Kebijakan Publik}

Implementasi kebijakan merupakan salah satu proses dari siklus kebijakan publik. Posisi implementasi kebijakan begitu penting dalam kebijakan publik, dimana pentingnya implementasi kebijakan dijelaskan oleh Wahab (2005), yaitu implementasi kebijakan lebih penting dari perumusan kebijakan. Winarno (2002) menjelaskan implementasi kebijakan publik adalah sebuah alat dimana berbagai aktor, organisasi, prosedur, danteknik bekerja bersama-sama untuk menjalankan kebijakan untuk mencapai tujuan yang diharapkan. Nugroho (2004) mendefinisikan implementasi kebijakan sebagai sebuah cara agar kebijakan dapat mencapai tujuannya. Kedua pendapat tersebut mempunyai kesimpulan yang sama, yaitu implementasi kebijakan merupakan sebuah cara untuk mencapai apa yang menjadi tujuan dari sebuah kebijakan. Pengertian dari Winarno menjelaskan implementasi lebih rinci dengan menjabarkan pihakpihak yang terlibat dalam implementasi kebijakan, seperti organisasi, aktor-aktor (pemerintah dan non pemerintah) dan sistem yang ada di dalam implementasi kebijakan itu sendiri.

Patton \& Sawicki (1987) menyatakan bahwa proses implementasi, merupakan seperangkat permainan dimana banyak aktor melakukan manuver tertentu untuk memperoleh apa yang mereka inginkan. Biasanya digunakan metode permainan (game) sebagai upaya memperoleh lebih sumber daya kebijakan, seperti mekanisme monitoring, renegosiasi sasaran yang telah di rumuskan setelah program berjalan dan atau dengan jalan menambah berbagai elemen baru dari program yang telah ada selama ini. Sebaiknya keseluruhan proses implementasi kebijakan dapat dievaluasi dengan cara mengukur atau membandingkan antara hasil akhir dari program - program tersebut dengan tujuan - tujuan kebijakan.

Selain itu Pressman dan Wildavsky

(1984) menyatakan sebagai berikut:

Implementation, to us, means just what Webster and Roger say it does; to carry out, accomplish fulfill, produce, comlete. But what is it being implemented? A policy, naturaly. There must be some thing out their prior to implementation; otherwise there would be nothing to move toward in the process of implementation. A verb like "implement" must have an object like "policy". But policies normally contain but goals and the mean for achieving them. How, then, do we distinguish between a policy and its implementation?.

Konsep Pressman dan Wildavsky diatas, mengindikasikan bahwa pada dasarnya implementasi adalah untuk melaksanakan kebijakan yang harus mempunyai objek dan dapat menimbulkan dampak tercapai atau tidaknya suatu kebijakan. Ripley dan Franklin (1986) menuntun pemikiran bahwa untuk memahami konsep implementasi kebijakan dibutuhkan pengertian tentang serangkaian kegiatan, yaitu sebagai berikut:

Implementation is what happens after laws are passed outhorizing a program, a policy, a benefit, or some kind of tangible output. The term refers to the set of activities the follow statements of intent about program goals and desired result by goerment officials, implementation encompasses action (and nanations) by e variety of actors, specially bureaucrats, designed to put programs into effect, ostensibility in such a way as to achive goals.

\subsection{Model Implementasi Kebijakan Publik}

Model implementasi kebijakan publik yang peneliti paparkan merupakan model implementasi kebijakan publik yang bersifat top-down. Peneliti hanya fokus pada model implementasi kebijakan publik yang bersifat top-down karena Kebijakan BPJS-Kesehatan merupakan kebijakan yang bersifat top-down, sehingga diperlukan pemaparan mengenai model implementasi kebijakan publik top-down untuk dapat memahami lebih jauh mengenai implementasi kebijakan BPJS-Kesehatan.

a) Model Van Meter dan Van Horn

Agustino (2006) menyebutkan bahwa model implementasi kebijakan Van Meter dan Van Horn mengharuskan adanya kesesuaian antara keputusan politik, pelaksana, dan kinerja kebijakan. Van Meter dan Van Horn memperkenalkan pendekatan implementasi kebijakan yang menghubungkan antara isu kebijakan dengan implementasi kebijakan dan kebijakan dengan kinerja. Van Meter dan Van Horn menjelaskan bahwa perubahan, kontrol, dan kepatuhan dalam tindakan merupakan konsep penting dalam prosedur implementasi. Berdasarkan model ini, terdapat enam variabel yang mempengaruhi implementasi kebijakan, ukuran dan tujuan kebijakan, sumber daya, karakteristik agen pelaksana, sikap pelaksana, komunikasi antar organisasi, dan kondisi, ekonomi, politik, dan sosial.

b) Model Daniel Mazmanian dan Paul A. Sabatier

Mazmanian dan Sabatier (Nugroho, 2006), mengklasifikasikan proses implementasi kebijakan ke dalam tiga variabel. Pertama, variabel independen, yaitu mudah-tidaknya masalah dikendalikan yang berkenan dengan indikator masalah teori dan teknis pelaksana, keragaman objek, dan perubahan seperti apa yang dikehendaki. Kedua, variabel intervening, yaitu variabel 
kemampuan kebijakan untuk menstrukturkan proses implementasi dengan indikator kejelasan dan konsistensi tujuan, dipergunakannya teori kausal, ketepatan alokasi sumber dana, keterpaduan hierarkis diantara lembaga pelaksana, aturan pelaksana, dan keterbukaan kepada pihak luar; dan variabel di luar kebijakan yang mempengaruhi proses implementasi yang berkenaan dengan indikator kondisi sosial ekonomi dan teknologi, dukungan publik, sikap dan resources dari konstituen, dukungan pejabat yang lebih tinggi, serta komitmen dan kualitas kepemimpinan dari pejabat pelaksana. Ketiga, variabel dependen, yaitu tahapan dalam proses implementasi dengan lima tahapan, yaitu pemahaman dari lembaga/ badan pelaksana dalam bentuk disusunnya kebijakan pelaksana, kepatuhan objek, hasil nyata, penerimaan atas hasil nyata tersebut, dan akhirnya mengarah kepada revisi atas kebijakan yang dibuat dan dilaksanakan tersebut atau keseluruhan kebijakan yang bersifat mendasar.

c) Model Brain W. Hogwood dan Lewis A. Gun

Nugroho (2006) menyatakan untuk melakukan implementasi kebijakan diperlukan beberapa syarat. Syarat pertama berkenaan dengan jaminan bahwa kondisi eksternal yang dihadapi oleh lembaga/ badan pelaksana tidak akan menimbulkan masalah yang besar. Syarat kedua adalah apakah untuk melaksanakannya tersedia sumber daya yang memadai, termasuk sumber daya waktu. Syarat ketiga apakah perpaduan sumbersumber yang diperlukan benar-benar ada. Syarat keempat adalah apakah kebijakan yang akan diimplementasikan didasari hubungan kausal. Jadi, prinsipnya adalah apakah kebijakan tersebut memang dapat menyelesaikan masalah yang hendak ditanggulangi. Syarat kelima adalah seberapa banyak hubungan kausalitas yang terjadi. Asumsinya, semakin sedikit hubungan "sebab-akibat", semakin tinggi pula hasil yang dikehendaki kebijakan tersebut dapat dicapai. Sebuah kebijakan yang mempunyai hubungan kausalitas yang kompleks, otomatis menurunkan efektivitas implementasi kebijakan. Syarat keenam adalah apakah hubungan saling ketergantungan kecil.

Syarat ketujuh adalah pemahaman yang mendalam dan kesepakatan terhadap tujuan. Syarat kedelapan adalah bahwa tugas-tugas telah dirinci dan ditempatkan dalam urutan yang benar. Tugas yang jelas dan prioritas yang jelas adalah kunci efektivitas implementasi kebijakan. Syarat kesembilan adalah komunikasi dan koordinasi yang sempurna. Komunikasi adalah perekat organisasi, dan koordinasi adalah asal muasal dari kerja sama tim serta terbentuknya sinergis. Syarat kesepuluh adalah bahwa pihak-pihak yang memiliki wewenang kekuasaan dapat menuntut dan mendapatkan kepatuhan yang sempurna. Kekuasaan atau power adalah syarat keefektifan implementasi kebijakan. Tanpa otoritas yang berasal dari kekuasaan, kebijakan akan tetap berupa kebijakan-tanpa ada dampak bagi target kebijakan

d) Model Goerge Edwards III

Dalam mengkaji implementasi kebijakan, Edwards membicarakan empat faktor atau variabel krusial dalam implementasi kebijakan publik. Faktor utama atau variabel-variabel tersebut adalah komunikasi, sumber daya, kecenderungan-kecenderungan atau tingkah laku, dan struktur birokrasi. Menurut Edwadrs III (1984), keempat faktor ini berpengaruh terhadap implementasi kebijakan dan bekerja secara simultan dan berinteraksi satu sama lain untuk membantu dan menghambat implementasi kebijakan, maka pendekatan yang ideal adalah dengan cara merefleksikan kompleksitas ini dengan membahasa semua faktor sekaligus.

Untuk memahami suatu implementasi kebijakan perlu disederhanakan, dan untuk menyederhanakan perlu merinci penjelasan-penjelasan tentang implementasi dalam komponen-komponen utama. Patut diperhatikan disini bahwa implementasi dari setiap kebijakan merupakan suatu proses yang dinamis yang cukup banyak interaksi dan banyak variabel. Oleh karena itu, tidak ada variabel tunggal dalam proses implementasi, sehingga perlu dijelaskan keterkaitan antara satu variabel dengan variabel yang lain dan bagaimana variabel-variabel ini mempengaruhi proses implementasi (Winarno, 2002).

\subsection{Diskresi}

Aaron (1964) menyatakan diskresi sebagai "power authority conferred by law to action on the basic of judgement of conscience, and its use is more than idea of morals than law". Selanjutnya, La Fave (1965) menyatakan bahwa diskresi merupakan sebuah pengambilan keputusan yang dipengaruhi oleh penilaian pribadi, tidak terikat dengan hukum yang berlaku. David (1969) menjelaskan bahwa "discretion is maybe defined as capacity of policy maker officers to select from among a number of legal and ilegal courses of action or inaction while performing their duties". David mempertegas diskresi dapat dilakukan dengan atau tanpa pertimbangan hukum, dengan kata lain diskresi yang dilakukan dapat menurut hukum (legal) atau tidak menurut hukum (ilegal). Lebih lanjut Marzuki (1996) menyatakan bahwa diskresi adalah kebebasan yang diberikan kepada tata usaha negara dalam rangka penyelenggaraan pemerintahan, sesuai dengan meningkatnya tuntutan pelayanan publik yang harus diberikan negara kepada masyarakat yang semakin kompleks.

Keputusan yang dibuat birokrat level bawah dalam memberikan pelayanan masyarakat, umumnya juga berpengaruh terhadap kelangsungan hidup masyarakat penerima layanannya. Oleh karena itu, mereka dituntut harus dapat memahami reaksi masyarakat secara 
personal terhadap keputusan pelayanan yang dibuat, terlebih lagi mereka harus mengatasi akibat dari keputusan yang mereka berikan dalam pelayanan masyarakat.

\subsection{Diskresi Menurut Michael Lipsky}

Lipsky menyoroti tentang adanya diskresi yang dapat terjadi. Lipsky (1980) mengatakan bahwa "unlike lower-level worker in most organization, street-level bureaucrats have considerable discretion in determining the nature, amount, and quality of benefits and sanctions provided by their agencies". Lipsky memaknai diskresi sebagai derajat kebebasan dalam menggunakan kewenangan oleh masing-masing individu, baik dalam proses pengambilan keputusan maupun pelaksanaan kebijakan sehubungan dengan pelayanan yang akan diberikan kepada masyarakat.

Adanya derajat kebebasan ini, dapat memungkinkan masing-masing birokrat level bawah dalam suatu organisasi pelayanan publik untuk menggunakannya dengan tujuan untuk meningkatkan kualitas pelayanan publik, meskipun dalam pelaksanaannya disesuaikan dengan kepentingan yang berbeda dan oleh dorongan yang juga tidak sama. Hal ini menyebabkan tidak seragamnya pelayanan yang diperoleh masyarakat oleh para birokrat level bawah.

Bentuk diskresi menurut Lipsky, adalah sebagai berikut:

a) Pembatasan terhadap akses dan permintaan

Birokrat level bawah membatasi akses dan permintaan dengan cara mempermainkan biaya pelayanan, waktu pelayanan, membatasi informasi, dan mempermainkan psikologi masyarakat.

b) Ketidakadilan administrasi

Barang publik dan pelayanan didistribusikan dengan menentukan biaya dan membatasi jumlahnya. Barang publik dan pelayanan juga didistribusikan dengan cara mendistribusikan sesuai dengan kelas masyarakat dan klaim dari masyarakat. Pelayanan publik didistribusikan secara berbeda oleh pemberi layanan berdasarkan empat sebab. Pertama, sebagian masyarakat menuntut birokrasi untuk dapat merespon dan mengerti kondisi mereka dalam upaya mendapatkan pelayanan. Kedua, pemberi layanan menginginkan adanya peningkatan dalam hidup masyarakat penerima layanan. Ketiga, pemberi layanan membutuhkan adanya pembedaan terhadap masyarakat penerima layanan. Keempat, pembedaan terhadap masyarakat membantu pemberi layanan dalam mengatur beban kerja mereka.

c) Mengatur masyarakat dan situasi kerja

Birokrat level bawah mengatur masyarakat dan mengatur situasi kerja dengan cara, yaitu sebagai berikut:
- Pemberi layanan berinteraksi dengan masyarakat dengan cara memperkuat peran mereka dan membatasi interaksi mereka dengan masyarakat;

- Interaksi antar pengguna layanan dibatasi. Birokrasi pelayanan disusun sedemikian rupa agar pengguna layanan tidak mengetahui kondisi pengguna layanan yang lain. Perlakuan ini mengakibatkan pengguna layanan berpikir bahwa yang bertanggung jawab atas diri mereka adalah diri mereka sendiri;

- Pelayanan yang diberikan oleh pemberi layanan diberikan dengan ramah kepada pengguna layanan. Hal ini mereka lakukan untuk membentuk opini pengguna layanan bahwa pelayanan yang mereka berikan berkualitas;

- Pengguna layanan berperan aktif dalam mendapatkan pelayanan;

- Interaksi dengan pengguna layanan didesain secara berjenjang, sehingga pemberi layanan dapat mengontrol tindakan, waktu, dan langkah yang diambil;

- Ketika mengontrol masyarakat pengguna layanan dihadapkan pada situasi yang sulit, interaksi antara pemberi dan penerima layanan dilakukan dengan mekanisme kontrol rutin. Beberapa pemberi layanan tidak dapat bergantung sepenuhnya pada sistem yang ada dalam mengontrol masyarakat pengguna layanan, oleh karena itu mereka menyusun sebuah agenda rutin yang bertujuan agar pengguna layanan secara inisiatif mempersiapkan diri mereka sebelum mendapatkan layanan; dan

- Pemberi layanan menciptakan sanksi untuk memberikan hukuman atas tindakan yang tidak mematuhi peraturan yang disusun oleh pemberi layanan.

d) Mempengaruhi mentalitas klien

Birokrat level bawah mempengaruhi mentalitas klien dengan cara, pertama mereka mengubah tujuan agar sesuai dengan kemampuan yang miliki. Kedua, mereka memberikan pelayanan yang minimal kepada masyarakat, hal tersebut mereka lakukan karena mereka tidak bisa memberikan pelayanan yang berkualitas kepada semua masyarakat pengguna layanan sesuai dengan standar yang telah ditentukan.

\section{Metode Penelitian}

\subsection{Jenis Penelitian}

Pendekatan yang digunakan dalam penelitian ini adalah pendekatan kualitatif. Pendekatan kualitatif digunakan dalam penelitian ini karena pendekatan kualitatif dilakukan untuk mengungkapkan sebuah fakta tertentu, melalui menghimpun data, dan kemudian dianalisis dengan sistematik dan terarah (Subagyo, 1999). 


\subsection{Fokus Penelitian}

Berdasarkan rumusan masalah yang telah dijabarkan, maka fokus dalam penelitian ini, adalah sebagai berikut:

a) Bentuk diskresi implementasi Kebijakan BPJS di Puskesmas Kepanjen

- Pembatasan terhadap akses dan permintaan;

- Ketidakadilan administrasi;

- Pengaturan pengguna layanan dan situasi kerja; dan

- Mempengaruhi mentalitas pengguna layanan.

b) Pengaruh diskresi terhadap Implementasi Kebijakan BPJS

- Langsung; dan

- Tidak langsung.

\subsection{Metode Penelitian}

Creswell (2009) menyatakan bahwa "It is an ongoing process involving continual reflection about the data, asking analytic questions, and writing memos throughout the study". Analisis data adalah sebuah proses yang melibatkan review data terus menerus, menyusun pertanyaan analisis, dan membuat catatancatatan. Creswell (2009) menjabarkan metode analisis data, yaitu sebagai berikut:

a) Menyiapkan data untuk di analisa. Pada tahapan ini meliputi merangkum hasil wawancara, mengorganisir catatan, dan memilah data berdasarkan sumber dan karakteristiknya;

b) Membaca keseluruhan data. Dalam tahap ini dapat diketahui informasi apa yang dapat diketahui secara umum, dan sudut pandang informan terhadap fenomena;

c) Melakukan proses koding. Koding dilakukan dengan mengelompokkan data menjadi detail yang lebih kecil berdasarkan fokus penelitian;

d) Mendeskripsikan fokus penelitian berdasarkan hasil koding. Hasil deskripsi merupakan hasil analisis peneliti berdasarkan koding sesuai dengan tema; dan

e) Interpretasi data. Setelah proses tersebut dilakukan, peneliti melakukan pengambilan kesimpulan.

\section{Hasil Penelitian dan Pembahasan}

\subsection{Hasil Penelitian}

Hasil penelitian menunjukkan bahwa birokrat level bawah di Puskesmas Kepanjen dalam mengimplementasikan kebijakan BPJS-Kesehatan patuh terhadap ketentuan yang ada. Masyarakat peserta BPJSKesehatan yang tidak terdaftar di Puskesmas Kepanjen tetap dapat mendapatkan pelayanan kesehatan, hal tersebut disebabkan adanya Peraturan Bupati Malang yang menyatakan bahwa pelayanan kesehatan di seluruh puskesmas se-Kabupaten Malang tidak dipungut biaya. Berdasarkan hasil wawancara, birokrat level bawah di
Puskesmas Kepanjen tidak berupaya untuk memanfaatkan kewenangan yang dimiliki untuk memperoleh keuntungan pribadi.

Hal tersebut disebabkan karena mereka memegang kuat norma profesi dan mereka memegang nilai-nilai kemanusiaan. Sehingga secara teoritis pola diskresi menurut Lipsky tidak terjadi pada implementasi Kebijakan BPJS-Kesehatan di Puskesmas Kepanjen. Pada implementasi kebijakan BPJS-Kesehatan, terjadi perubahan pola komunikasi antar stakeholders pelaksana, pada gambar 1 dapat dilihat pola komunikasi antar stakeholders pelaksana Kebijakan BPJSKesehatan antara Kantor BPJS-Kesehatan Malang, Dinas Kesehatan Kabupaten Malang, dan Puskesmas di Kabupaten Malang.

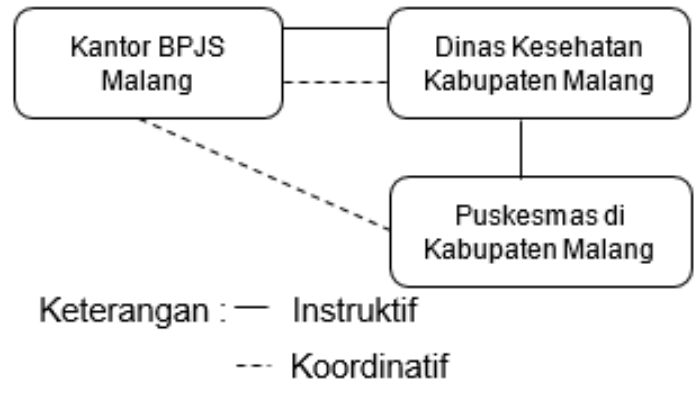

Gambar 1 Pola komunikasi antar stakeholders dalam implementasi Kebijakan BPJS-Kesehatan Sumber: Hasil analisis, 2015

Berdasarkan gambar 1, pola hubungan antara Kantor BPJS Malang dengan Puskesmas di Kabupaten Malang hanya sebatas pola koordinatif, sedangkan pola hubungan antara Kantor BPJS Malang dengan Dinas Kesehatan Kabupaten Malang bersifat instruktif. Sehingga dapat disimpulkan bahwa jika Kantor BPJS Malang ingin memberikan perintah kepada Puskesmas di Kabupaten Malang, harus melalui Dinas Kesehatan Kabupaten Malang. Namun pada kenyataan pola tersebut berubah seperti yang digambarkan pada gambar 2, yaitu sebagai berikut:

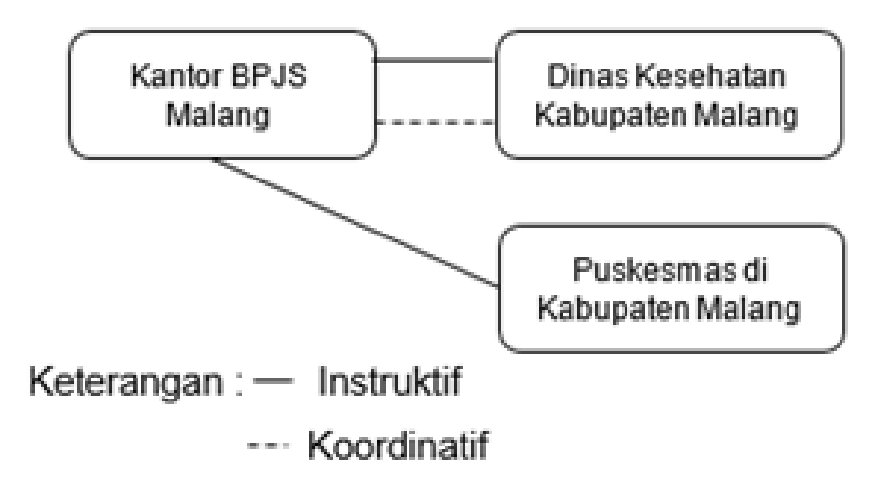

Gambar 2 Pola komunikasi antar stakeholders dalam implementasi Kebijakan BPJS-Kesehatan Sumber: Hasil analisis, 2015 
Berdasarkan gambar 2 tersebut dapat diketahui bahwa pola hubungan antara Kantor BPJS Malang dengan Puskesmas di Kabupaten Malang bersifat instruktif. Berdasarkan hasil wawancara, perubahan pola tersebut membawa dampak yang positif terhadap implementasi Kebijakan BPJS-Kesehatan, permasalahan yang ada terkait Implementasi Kebijakan BPJSKesehatan di Puskesmas se-Kabupaten Malang dapat langsung dipecahkan dengan pola komunikasi tersebut. Namun di satu sisi Kantor BPJS Malang sering kali memberikan instruksi terkait implementasi Kebijakan BPJS-Kesehatan berdasarkan pola komunikasi tersebut.

Diskresi yang tidak terjadi pada implementasi Kebijakan BPJS-Kesehatan di Puskesmas Kepanjen secara langsung berpengaruh terhadap pelayanan kesehatan di Puskesmas Kepanjen. Pelayanan kesehatan dalam rangka implementasi Kebijakan BPJS-Kesehatan dapat berjalan dengan efektif dan efisien terlepas dari keterbatasan sumber daya yang ada. Pengaruh tidak langsung terkait diskresi yang terjadi tidak ditemukan dalam implementasi Kebijakan BPJS-Kesehatan di Puskesmas Kepanjen.

\subsection{Pembahasan}

Disreksi yang tidak terjadi dalam implementasi Kebijakan BPJS-Kesehatan di Puskesmas Kepanjen disebabkan karena norma profesi dan nilai kemanusiaan yang dipegang teguh oleh birokrat level bawah di Puskesmas Kepanjen. Hal ini bertentangan dengan apa yang disampaikan oleh Lipsky, yaitu norma profesi merupakan salah satu faktor yang menyebabkan terjadinya diskresi. Peneliti berpendapat bahwa karakteristik pelayanan kesehatan berbeda dengan karakteristik pelayanan publik lainnya seperti pelayanan perijinan, pelayanan kependudukan, dan lain-lain. Pada pelayanan kesehatan, dapat dikatakan risiko yang dihadapi lebih tinggi daripada pelayanan lainnya. Perubahan pola hubungan antar stakeholders membawa dampak yang baik dalam implementasi Kebijakan BPJS-Kesehatan, namun dampak negatif tetap dapat terjadi. Untuk mencegah hal tersebut peran Dinas Kesehatan Kabupaten Malang harus diperkuat.

\subsection{Upaya yang Dapat Ditempuh Untuk Meningkatkan Kualitas Implementasi Kebijakan BPJS-Kesehatan}

a) Mengganti Sistem Kapitasi yang Digunakan Oleh Fasilitas Kesehatan Tingkat Pertama Untuk Mengatur Keuangannya

Hal yang menyebabkan tidak fleksibelnya fasilitas kesehatan tingkat pertama dalam memberikan layanan kesehatan khususnya kepada masyarakat peserta BPJSKesehatan yang tidak terdaftar di faskes tersebut, disebabkan oleh sistem keuangan yang menganut sistem kapitasi. Anggaran yang diterima oleh faskes tergantung berdasarkan jumlah masyarakat yang terdaftar di faskes tersebut, oleh karena itu masyarakat yang tidak terdaftar di faskes tersebut tidak dapat dilayani karena secara keuangan mereka menjadi beban faskes tersebut dan biaya tersebut tidak dapat diklaim kepada BPJSKesehatan. Skema tersebut dapat dilihat pada gambar 3, yaitu sebagai berikut:

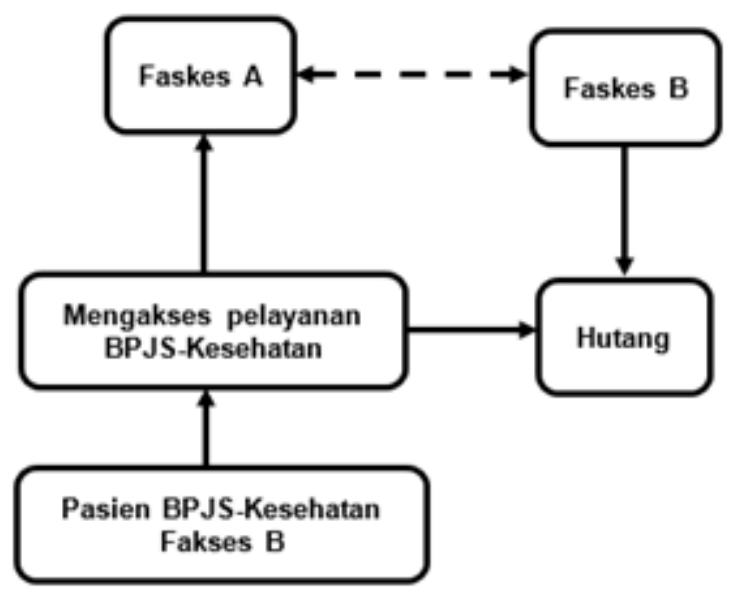

Gambar 3 Analisis Skema Keuangan Kebijakan BPJSKesehatan Menurut Peneliti Sumber: Hasil analisis, 2015

Pada skema tersebut terdapat dua fasilitas kesehatan tingkat pertama, yaitu Faskes A dan Faskes B. Terdapat peserta BPJS-Kesehatan yang terdaftar di Faskes B ingin berobat ke Faskes A. Sesuai dengan skema hasil analisis peneliti, Faskes A harus menerima pasien tersebut. Setelah terlayani oleh Faskes A, maka Faskes A mempunyai piutang kepada Faskes B sesuai dengan Faskes yang terdaftar pada pasien tersebut. Piutang yang dimiliki oleh Faskes A kepada Faskes B adalah piutang biaya pemeriksaan oleh dokter, biaya laboratorium (jika ada) dan biaya obat. Piutang tersebut dapat di bayar oleh Faskes B kepada Faskes A paling lambat 30 hari setelah pasien tersebut memeriksakan diri di Faskes A.

Dengan menerapkan skema utang-piutang antar Fasilitas Kesehatan Tingkat Pertama tersebut, maka masyarakat peserta BPJS-Kesehatan dapat terlayani di seluruh Fasilitas Kesehatan Tingkat Pertama SeIndonesia. Selain itu secara anggaran, skema tersebut dapat mengatasi permasalahan siapa yang akan membayar biaya pengobatan jika pasien tersebut tidak terdaftar di Faskes tersebut. Proses pembayaran hutangpiutang dapat melalui nomor rekening yang dimiliki oleh masing-masing Faskes, sehingga mempermudah proses pembayaran.

b) Pusat Data peserta BPJS-Kesehatan yang Terpusat dan Dapat Diakses oleh Stakeholder Pelaksana Kebijakan BPJS-Kesehatan

Terkait dengan pelaksanaan skema keuangan sebagaimana digambarkan pada gambar 3, sistem database yang terpusat dan real time sangat penting. Mengenai gambaran penggunaan database sesuai 
dengan skema yang peneliti sarankan dapat dilihat pada gambar berikut:

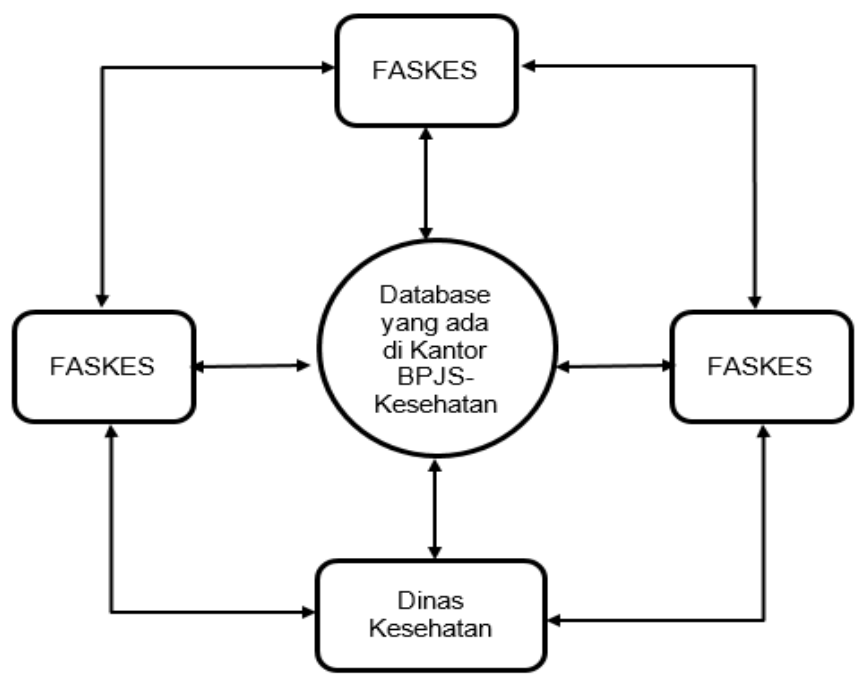

Gambar 4 Skema Penggunaan Database BPJS-

Kesehatan oleh Stakeholders

Sumber: Hasil analisis, 2015

Database BPJS-Kesehatan harus dapat diakses oleh stakeholders pelaksana kebijakan secara real time dan stakeholders dapat bertukar data antara satu dengan yang lainnya. Database tersebut tidak hanya berisi tentang profil kepesertaan dan status kepesertaan BPJSKesehatan saja, tetapi juga mencakup status mutasi faskes, perpindahan kelas, tunggakan premi, history penggunaan layanan BPJS-Kesehatan oleh peserta. Database tersebut nantinya dijadikan pedoman masingmasing faskes dalam menyusun laporan administrasi dan laporan keuangannya. Pada laporan administrasi dan laporan keuangan faskes secara berkala tersebut dapat dilihat hutang dan piutang yang dimiliki oleh faskes tersebut terhadap faskes lainnya.

Keuntungan yang diperoleh dari hal tersebut adalah proses kontrol terhadap keadaan anggaran dan perkembangan peserta BPJS-Kesehatan dapat dilihat secara real time dan transparan. Kantor BPJS-Kesehatan dan dinas kesehatan dapat memverifikasi secara langsung dan tidak akan terdapat kesalahan data yang digunakan pada waktu pelaporan oleh faskes. Sehingga keputusan-keputusan strategis terkait implementasi Kebijakan BPJS-Kesehatan dapat diambil secara tepat.

c) Adanya Payung Hukum yang Mengatur Agar Puskesmas Dapat Mengelola Anggaran BpjsKesehatan Secara Mandiri

Pengelolaan anggaran BPJS-Kesehatan pada Puskesmas berbeda dengan faskes swasta, hal tersebut disebabkan karena puskesmas tidak menyandang status sebagai Badan Layanan Umum (BLU) dan puskesmas berada dibawah koordinasi dinas kesehatan. Sehingga penganggaran keuangan harus melalui dinas kesehatan, termasuk penganggaran keuangan BPJS-Kesehatan. Hal tersebut menurut peneliti akan membuat puskesmas tidak akan dapat bergerak dengan leluasa untuk memberikan pelayanan kesehatan yang efektif dan efisien.

Terkait Kebijakan BPJS-Kesehatan, anggaran untuk puskesmas harus melalui dinas kesehatan terlebih dahulu dan setelah itu akan didistribusikan oleh dinas kesehatan ke masing-masing puskesmas. Hal tersebut yang menjadikan pelayanan puskesmas kurang dapat berkembang dengan baik, berbeda dengan pelayanan yang diberikan oleh faskes swasta yang ada. Oleh karena itu peneliti menyarankan agar terdapat payung hukum yang mengatur agar khusus puskesmas dapat mengelola anggaran BPJS-Kesehatan secara mandiri, sehingga dapat meningkatkan kualitas pelayanan kesehatan.

\section{Kesimpulan}

Penelitian ini menyimpulkan bahwa norma profesi dan nilai kemanusiaan yang dianut oleh birokrat level bawah di Puskesmas Kepanjen berperan dalam tidak adanya diskresi yang terjadi pada Implementasi Kebijakan BPJS-Kesehatan di Puskesmas Kepanjen. Desain pelayanan yang sederhana dan perbedaan karakteristik pelayanan juga menyebabkan tidak terjadinya diskresi dalam Implementasi Kebijakan BPJS-Kesehatan di Puskesmas Kepanjen.

\section{Daftar Pustaka}

Aaron, Thomas J. (1964). The Control of Policy Discretion. Springfield: Charles C. Thomas Co.

Agustino, Leo. (2006). Dasar-dasar Kebijakan Publik. Bandung: CV Alfabeta.

Brockmann, J. (2015). Unbureaucratic Behavior among Street-Level Bureaucrats The Case of the German State Police. Review of Public Personnel Administration. July 2015, pp. 1-22.

Creswell, John W. (2009). Research Design: Qualitative, Quantitative and Mixed Methods Approaches. California: Sage Publication Inc.

David, K.C. (1969). Discretionary Justice: A Preliminary Inquiry. Baton Rouge: Louisiana State University Press.

Edward III, George C. (1984). Public Policy Implementing. Jal Press Inc, London.

LaFave, Wayne R. (1965). Arrest The Decision to Take a Suspect into Castody. Little Brow and Company, Boston.

Lipsky, Michael. (1980). Street Level Bureaucracy, Dilemmas of The Individual In Public Services. New York: Russel Sage Foundation.

Marzuki, Laica. (1996). Kebijakan yang diperjanjikan (Beleidsovereenkornst). Makalah Pada Penataran Nasional Hukum Acara Dan Hukum 
Administrasi Negara, Fakultas Hukum Universitas Hasanudin, Makassar.

Nugroho, Riant. (2004). Kebijakan Publik: Formulasi, Implementasi, dan Evaluasi. Jakarta: Media Elex Computindo.

Nugroho, Riant. (2006). Kebijakan Publik untuk Negara-negara Berkembang (Model-model Perumusan Implementasi dan Evaluasi). Jakarta: PT. Elex Media Komputindo.

Patton, C.V., \& Sawicki, D.S. (1987). Basic Methods of Policy Analysis \& Planning. New Jersey: Prentice-Hall.

Pressman, J.L., \& Wildavsky, Aaron. (1984). Implementation. California: University of California Press and Los Angles.

Ripley, Ronald B., \& Franklin, Grace. (1986). Policy Implementation Bureaucracy. Chicago: Dorsey Press.

Subagyo, Joko. (1999). Metode Penelitian dalam Teori dan Praktek. Jakarta: Rineka Cipta.

Wahab, Solicin Abdul. (2005). Analisis Kebijakan: Dari Formulasi ke Implementasi Kebijakan Negara. Jakarta: PT. Bumi Aksara.

Widaningrum, A. (2007). Street Level Bureaucracy: Dillemmas of Providers in Health Centres. Department of Public Administration, Faculty of Social and Political Sciences Gadjah Mada University, Yogyakarta.

Winarno, Budi. (2002). Teori dan Proses Kebijakan Publik. Yogyakarta: Media Presindo. 